\title{
The effect of ethanol extract of soursop leaf (Annona muricata L.) on adhesion of Streptococcus mutans ATCC 35668 to hydroxyapatite discs
}

\author{
Friska Ani Rahman*, Tetiana Haniastuti ${ }^{\star *}$, Trianna Wahyu Utami ${ }^{\star \star *}$ \\ *Dental Hygiene Program, Faculty of Dentistry, Universitas Gadjah Mada, Yogyakarta, Indonesia \\ ${ }^{* *}$ Department of Oral Biology, Faculty of Dentistry, Universitas Gadjah Mada, Yogyakarta, Indonesia \\ ${ }^{* * *}$ Department of Dental Biomedical Sciences, Faculty of Dentistry, Universitas Gadjah Mada, Yogyakarta, Indonesia \\ *JI Denta No 1 Sekip Utara, Yogyakarta, Indonesia; e-mail: friska_ani@ugm.ac.id
}

Submitted: $8^{\text {th }}$ May 2017; Revised: 30 ${ }^{\text {th }}$ November 2017; Accepted: $12^{\text {nd }}$ December 2017

\begin{abstract}
The demineralization of dental hard tissues can be caused by dental plaque. Dental plaque contains various components, especially bacteria attached to the extracellular matrix. Streptococcus mutans (S. mutans) has extracellular glucan as adhesin that is important in the attachment mechanism of tooth surface. The natural substance can be used for preventing plaque formation by inhibiting the attachment of $S$. mutans. Soursop plant has been used in treating various diseases. The leaves of the soursop (Annona muricata L.) are used as a material to inhibit potential attachment of bacteria $S$. mutans. Common surfaces that is used in adhesion testing is hydroxyapatite (HA). The aim of this study was to evaluate the effect of ethanol extract of soursop leaf (EESL) on the adhesion of S. mutans ATCC 35668 to HA discs. Soursop leaves were extracted by the maceration method using $70 \%$ ethanol. The experiment was carried out by analyzing the inhibition adhesion of S. mutans ATCC 35668 on HA discs after incubation with different concentrations of soursop leaf extract. The concentrations of extract tested were: $150 ; 125 ; 100 ; 75$; and $50 \mathrm{mg} / \mathrm{ml}$. Chlorhexidine $0.2 \%$ was used as a positive control while DMSO $5 \%$ was used a negative one. Data were evaluated by One Way Anova. This study statistically showed significant differences of $S$. mutans colony count between groups $(p<0.05)$. The results of a post hoc Dunnett T3 test showed that the 2 highest concentrations of extract $(125$ and $150 \mathrm{mg} / \mathrm{ml}$ ) reduced $S$. mutans adhesion on HA discs. The obtained results showed that ethanol extract of soursop leave inhibits the adherence of $S$. mutans to the HA disc.
\end{abstract}

Keywords: adhesion; ethanol extract of soursop leaf (Annona muricata L.); hydroxyapatite discs; Streptococcus mutans

\section{INTRODUCTION}

Dental caries is a disease that destroys the tooth structure which is indicated with demineralization of dental hard tissue. This is view of the accumulation of plaque on the tooth surface..$^{1}$ Dental plaque is a bacterial deposit, and its product attaches to the tooth surface. ${ }^{2}$ Streptococcus mutans (S. mutans) plays an important role in the formation of dental caries. ${ }^{3}$ It has surface protein antigen peptide (SpaP), Ag I/II family proteins, that will bind to receptors on the pellicle on the tooth surface. The adhesion of $S$. mutans to the tooth surface is also influenced by the enzyme glucosyltransferase (GTF) which is capable to convert sucrose into glucan. Glucan plays an important role in facilitating bacteria adherence on the tooth surface which is lead to the increasing accumulation of plaque and initiate caries on the tooth surface. ${ }^{4}$
The prevention of $S$. mutans attachment is an effort in reducing the incidence of caries. One approach to reducing the incidence of caries is to develop the therapeutic agents with antimicrobial and antiadherent properties to prevent the bacterial adhesion on the tooth surface. ${ }^{5}$ One of the medicinal plants used in several regions in Indonesia is soursop (Annona muricata L.) ${ }^{6}$ in which its leaves are the part of the soursop plants which is widely used. ${ }^{7}$ In our previous studies, it showed that the ethanol extract of soursop leaf (EESL) contain secondary metabolites including saponins, terpenoids, steroids, flavonoids, tannins and alkaloids. The EESL inhibit the growth of S. mutans ATCC 35668 in a dosedependent manner. ${ }^{8}$ The inhibition of the adherence of S.mutans to the surface of the tooth is necessary for the prevention of plaque formation. Therefore, in this study, we investigated the inhibitory effect the EESL on the adhesion of $S$. mutans to HA discs 
which have been used as one of the experimental model systems. HA discs are the bacterial adhesion objects to simulated tooth enamel structure. Tooth enamel is composed of $99 \%$ inorganic compounds of $\mathrm{HA} .^{9}$

\section{MATERIALS AND METHODS}

This was a laboratory study. This study has been approved by The Research Ethics Team of Faculty of Dentistry Universitas Gadjah Mada with the number: 00247/KKEP/FKG-UGM/EC/2015.

Soursop leaves were obtained from Balai Besar Penelitian dan Pengembangan Tanaman Obat dan Obat Tradisional $\left(\mathrm{B}_{2} \mathrm{P}_{2}\right.$ TOOT) Tawangmangu, Ministry of Health, Indonesia. The leaves have been identified in $\mathrm{B}_{2} \mathrm{P}_{2}$ TOOT and extracted by the maceration method in Laboratorium Penelitian dan Pengujian Terpadu (LPPT) UGM. A reference stock of S. mutans (ATCC $\odot$ 35668) was used as a standardized suspension. Mc Farland standard solution $\left(1.5 \times 10^{8} \mathrm{CFU} / \mathrm{ml}\right)$ was used as the bacterial suspension turbidity standard.

HA discs were prepared as described by Guan. ${ }^{10}$ HA discs ( $\phi 10 \mathrm{~mm} \times 2 \mathrm{~mm}$ ) were made by pressing HA particles by Universal Testing Machine with 4 kgf pressure (Pharmacy Technology Laboratory of Faculty of Pharmacy UGM). HA discs were then sintered $\left(120 \mathrm{~min}, 1300^{\circ} \mathrm{C}\right)$ through the heating of $5{ }^{\circ} \mathrm{C} /$ minute in air atmosphere to obtain a solid HA discs (Ceramics and Composite Technology Laboratory of Chemical Engineering Department of Faculty of Engineering UGM). HA discs were sterilized by autoclave $\left(121^{\circ} \mathrm{C}, 20 \mathrm{~min}\right)$.

Whole saliva was collected from a healthy volunteer (dental conditions free from cavities and good oral hygiene) based on methods described previously. ${ }^{11}$ Fresh saliva samples were collected without stimulation and obtained in the morning without stimulation. The samples were dispersed using vortex mixer for $60 \mathrm{~min}$ and centrifuged at $20,000 \mathrm{rcf}$ for $60 \mathrm{~min}$ at $4{ }^{\circ} \mathrm{C}$. The supernatant was filtered through two low-protein-binding filters (pore sizes of $0.45 \mu \mathrm{m}$ and $0.22 \mu \mathrm{m}$ ).
The assay of $S$. mutans adhesion on HA discs. was done according to Lee, et.al. ${ }^{12} \mathrm{~S}$. mutans was cultured on $\mathrm{BHI}$ for $24 \mathrm{~h}$ at $37^{\circ} \mathrm{C}$. A total of 14 discs $\mathrm{HA}$ were coated with saliva for $1 \mathrm{~h}$ at the room temperature. The saliva-coated HAdiscs (S-HAdisc) were washed 3 times with potassium phosphate buffer (KPB) pH 7.0 and $2 \mathrm{HA}$ discs were added to every tube. Everytube was filled with $0.5 \mathrm{ml}$ EESL at different concentration $(150 ; 125 ; 100 ; 75 ; 50 \mathrm{mg} /$ $\mathrm{ml}$ ) and $0.5 \mathrm{ml}$ of a suspension of bacteria $S$. mutans ATCC $35668\left(1.5 \times 10^{7} \mathrm{CFU} / \mathrm{ml}\right)$. Positive control tube contained $0.5 \mathrm{ml}$ Chlorhexidine $0.2 \%$ and 0.5 $\mathrm{ml}$ of a suspension of bacteria S. mutans $\left(1.5 \times 10^{7}\right.$ CFU $/ \mathrm{ml}$ ). Negative control tube contained $0.5 \mathrm{ml}$ $5 \%$ DMSO and $0.5 \mathrm{ml}$ of a suspension of bacteria S. mutans $\left(1.5 \times 10^{7} \mathrm{CFU} / \mathrm{ml}\right)$. Based on a method as described by Anggraeni ${ }^{13}$ tubes were incubated for 24 hours at $37^{\circ} \mathrm{C}$. HA discs were washed with $\mathrm{KPB}$ and transferred into a tube containing $\mathrm{KPB}(\mathrm{pH}$ 7.0). S. mutans adsorbed onto the HA discs was dispersed using vortex for 60 seconds, diluted and spread on trypticase soy-sucrose-bacitracin agars (TYS20B) plates. After incubation for $24 \mathrm{~h}$ at $37^{\circ} \mathrm{C}$ number of bacterial colonies were counted on each TYS20B plate. Five replicates were made for each concentration of test extracts, and the number of Colony Forming Unit (CFU) was calculated.

\section{RESULTS}

The bacterial adherence assay was performed to determine whether EESL inhibits $S$. mutans adherence to HA discs. As shown in Figure 1, the adhesion of $S$ mutans to HA disc decreased following the increasing concentrations of EESL. ESSL inhibited the adherence of $S$. mutans completely at concentration $150 \mathrm{mg} / \mathrm{ml}$. One Way Anova test showed a significant value of $0.000 \quad(p<0.05)$ showing asignificant difference between groups. This showed that EESL has a significant effect on a number of colonies of $S$. mutans attaching on HA discs. The post hoc Dunnet T3 test was conducted to determine the differences among groups Table 1 . 


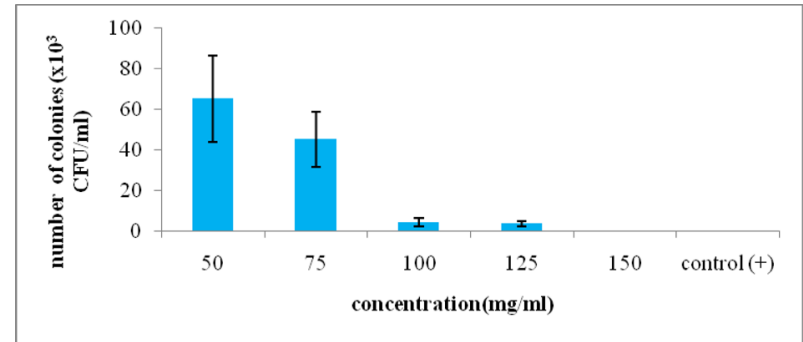

Figure 1. Effect of EESL on $S$. mutans adherence to salivacoated HA discs. The CFU of S. mutans to S-HA discs by various concentrations of EESL was determined.

Table 1. Post hoc analysis of $S$. mutans adherence to salivacoated HA discs among groups

\begin{tabular}{|c|c|c|}
\hline \multicolumn{2}{|c|}{ Among groups } & \multirow{2}{*}{$\frac{p}{0.765}$} \\
\hline $50 \mathrm{mg} / \mathrm{ml}$ & $75 \mathrm{mg} / \mathrm{ml}$ & \\
\hline & $100 \mathrm{mg} / \mathrm{ml}$ & $0.028^{*}$ \\
\hline & $125 \mathrm{mg} / \mathrm{ml}$ & $0.027^{*}$ \\
\hline & $150 \mathrm{mg} / \mathrm{ml}$ & $0.022^{*}$ \\
\hline & Negative control & $0.010^{*}$ \\
\hline & Positive control & $0.022^{*}$ \\
\hline \multirow[t]{5}{*}{$75 \mathrm{mg} / \mathrm{ml}$} & $100 \mathrm{mg} / \mathrm{ml}$ & $0.022^{*}$ \\
\hline & $125 \mathrm{mg} / \mathrm{ml}$ & $0.021^{*}$ \\
\hline & $150 \mathrm{mg} / \mathrm{ml}$ & $0.016^{*}$ \\
\hline & Negative control & $0.009^{*}$ \\
\hline & Positive control & $0.016^{*}$ \\
\hline \multirow[t]{4}{*}{$100 \mathrm{mg} / \mathrm{ml}$} & 125 mg/ml & 1,000 \\
\hline & $150 \mathrm{mg} / \mathrm{ml}$ & 0.071 \\
\hline & Negative control & $0.007^{*}$ \\
\hline & Positive control & 0.071 \\
\hline \multirow[t]{3}{*}{$125 \mathrm{mg} / \mathrm{ml}$} & $150 \mathrm{mg} / \mathrm{ml}$ & $0.019^{*}$ \\
\hline & Negative control & $0.007^{*}$ \\
\hline & Positive control & $0.019^{*}$ \\
\hline \multirow[t]{2}{*}{$150 \mathrm{mg} / \mathrm{ml}$} & Negative control & $0.006^{*}$ \\
\hline & Positive control & - \\
\hline $\begin{array}{l}\text { Negative } \\
\text { control }\end{array}$ & Positive control & $0.006^{*}$ \\
\hline
\end{tabular}

${ }^{*} p<0.05$ was statistically significant

Several concentrations of the extract were tested regarding their effect on adhesion of $S$. mutans on HA discs (Table 1). The results for 2 highest concentrations of extract that reduced S.mutans adhesion on HA discs. The results of a post hoc Dunnett T3 test showed that the group treated with $125 \mathrm{mg} / \mathrm{ml}$ significantly decreased in colony counts compared with the negative control and lower concentrations. The group treated with $150 \mathrm{mg} / \mathrm{ml}$ EESL showed no difference from positive control indicating that the concentration was effective in reducing the bacterial adherence to HA discs.

\section{DISCUSSION}

In the present study, the adhesion of $S$. mutans was evaluated using saliva-coated HA discs (S-HA disc). HA is common materials to analyze bacterial adherence. ${ }^{14}$ Saliva was used in this study for containing a glycoprotein that plays an important role in the bacterial adhesion in plaque formation. ${ }^{15} \mathrm{BHI}$ was used as growth medium without any sucrose to allow the adhesion of $S$. mutans in the form of non-specific attachment followed by the specific attachment of interaction independent on sucrose through adhesion of $S$. mutans binding to salivary glycoprotein attaching to HA discs. ${ }^{16}$

One-way analysis of variance (ANOVA), test on the effect of various concentrations of EESL on the adherence of $S$. mutans on the HA discs showed that EESL could significantly decrease the number of colonies. The group treated with $125 \mathrm{mg} / \mathrm{ml}$ showed a significant decrease in colony counts compared with the negative control and lower concentrations. The group treated with $150 \mathrm{mg} / \mathrm{ml}$ EESL showed no difference from positive control indicating that the concentration was effective in reducing bacterial adherence to HA discs. This might be the active compound in EESL reducing the bacterial colonies adhering to the HA discs.

The early phases of adhesion of $S$. mutans bacteria on the surface of the HA discs occur through non-specific attachment. One of the non-specific attachments is the hydrophobicity interaction between the cell and the adherence surface. A decrease in the hydrophobicity between the cell and the surface prevents bacterial adherence leading to a decrease bacteria attached to a surface. ${ }^{17,18}$ The ability of the extract to prevent the adherence of $S$. mutans could be related to the effect of saponins and flavonoids components. Saponins are known to have a hydrophobic and hydrophilic action. Hydrophobicity of saponin allows binding to hydrophobic end of the bacterial cell membrane while the hydrophilic end is a free end and will bring a complex detergentprotein resulting in bacterial lysis. ${ }^{19}$ Flavonoids through their antibacterial action is to form a 
complex with proteins through nonspecific forces such as hydrogen bonding and hydrophobic effects, and covalent bond formation. ${ }^{20}$ In the next phase, adhesin-specific attachment of $S$. mutans that bind to glycoproteins of saliva adhering to HA discs. This specific attachment is thought to be inhibited by EESL through tannins and flavonoids. According to Agnol $^{21}$ tannins works by binding bacterial adhesin protein that binds to receptors on the surface of the host, Bennick ${ }^{22}$ stated that the weakening bond with the bacterial cell surface protein on pellicle (host) would result in decreased bacterial adhesions. According to Kumar and Pandey ${ }^{20}$ flavonoids can inactivate the bacterial adhesion and a disturbance in the bacterial adhesion will lead to a decrease in bacterial adhesion. In conclusion, this study showed the anti-adhesive properties of EESL inhibit adherence of S. mutans to the HA disc.

\section{REFERENCES}

1. Lamont RJ, Jenkinson HF. Oral microbiology at a glance. Wiley-Blackwell. UK. 2008:34 - 35.

2. Marsh PD, Nyvad B. The oral microflora and biofilm on teeth. in Fejerskov O, Kidd E, (ed.): Dental caries the diseases and its clinical management $2^{\text {nd }}$ ed. Blackwell Munksgaard.UK. 2008: 164 - 178.

3. Brighenti FL, Luppens SBI, Delbem ACB, Deng DM, Hoogenkamp MA, Gaetti-Jardim JrE, Dekker $\mathrm{HL}$, Crielaard W, Cate JM. Effect of Psidium cattleianum leaf extract on Streptococcus mutans viability, protein expression and acid production. Caries Res. 2008; 42: 148 - 154.

4. Marsh PD, Martin MV. Oral microbiology $5^{\text {th }}$ ed. Churchill Livingstone. Elsevier. 2009: 80 - 85.

5. Nostro A, Cannatelli MA, Crisafi G, Musolino AD, Procopio F, Alonzo V. Modifications of hydrophobicity, in vitro adherence and cellular aggregation of Streptococcus mutans by Helichrysum italicum extract. Lett Appl Microbiol. 2004; 38: $423-427$.

6. Tambunan S. Ensiklopedi tanaman obat tradisional. Materi Medika. Jakarta. 2011: 47-68.
7. Foong CP, Hamid RA. Evaluation of antiinflammatory activities of ethanolic extracts of Annona muricata leaves. Rev Bras Farmacogn Braz J Pharmacogn. 2012; 22(6): 1301 - 1307.

8. Rahman FA, Haniastuti T, Utami TW. Skrining fitokimia dan aktivitas antibakteri ekstrak etanol daun sirsak (Annona muricata L.) pada Streptococcus mutans ATCC 35668. Majalah Kedokteran Gigi Indonesia. 2017; 3(1): 1 - 7.

9. ten Cate JM, Larsen MJ, Pearce EIF, Fejerskov O. Chemical interactions between the tooth and oral fluids in Fejerskov $\mathrm{O}$ and Kidd $\mathrm{E}$, (ed.): Dental Caries The Diseases and its Clinical Management. $2^{\text {nd }}$ ed. Blackwell Munksgaard.UK. 2008: 210 - 213 .

10. Guan YH, Lath DL, de Graaf T, Lilley TH, Brook $\mathrm{AH}$. Moderation of oral bacterial adhesion on saliva-coated hydroxyapatite by polyaspartate. J Appl Microbiol. 2003; 94: 456 - 461.

11. Hauser-Gerspach I, Kulik EM, Weiger R, Decker EM, Von Ohle C, Meyer J. Adhesion of Streptococcus sanguinis to dental implant and restorative materials in vitro. Dent Mater J. 2007; 26(3): $361-366$.

12. Lee D-H, Seo B-R, Kim H-Y, Gum G-C, Yu H-H, You H-K, Kang TH, You Y-O. Inhibitory effect of aralia continentalis on the cariogenic properties of Streptococcus mutans. J Ethnopharmacol. 2011; 137: 979 - 984.

13. Anggraeni A, Yuliati A, Nirwana I. Perlekatan koloni Streptococcus mutans pada permukaan resin komposit sinar tampak. Majalah Kedokteran Gigi Indonesia. 2005; 38(1): 8 - 11.

14. Forssten SD, Björklund M, Ouwehand AC. Streptococcus mutans, caries and simulation models. Nutrients. 2010; 2: 290 - 298.

15. Razak FA, Rahim ZHA. The anti-adherence effect of Piper betle and Psidium guajava extracts on the adhesion of early settlers in dental plaque to saliva-coated glass surfaces. J Oral Sci. 2003; 45(4): $201-206$. 
16. Banas JA. Virulence properties of Streptococcus mutans. Front BiosciLandmrk. 2004; 9: $1267-1277$.

17. Hasan S, Danishuddin M, Khan AU. Inhibitory effect of Zingiber officinale towards Streptococcus mutans virulence and caries development: in vitro and in vivo studies. BMC Microbiol. 2015; 15(1): 1 - 14 .

18. Khan R, Zakir M, Khanam Z, Shakil S, Khan AU. Novel compound from Trachyspermum ammi (ajowan caraway) seeds with antibiofilm and antiadherence activities against Streptococcus mutans: a potential chemotherapeutic agent against dental caries. J Appl Microbiol. 2010; 109: $2151-2159$.
19. Aswal D, Beatrice L. Daya antibakteri ekstrak buah mahkota dewa (Phaleria macrocarpa) terhadap Enterococcus faecalis (in vitro). J Dentika Dent. 2010; 6: 35.

20. Kumar S, Pandey AK. Chemistry and biological activities of flavonoids: an overview. The Scientific World Journal. 2013; 1 - 16.

21. Agnol RD, Ferraz A, Bernardi AP, Albring D, Nor C, Sarmentom L, Lamb L, Hass M, von Poser $\mathrm{G}$, Schapoval EES. Antimicrobial activity of some Hypericum species. Phytomedicine. 2003; 10 : $511-516$.

22. Bennick A. Interaction of plant polyphenols with salivary proteins. Crit Rev Oral Biol Med. 2002; 13(2): $184-196$. 